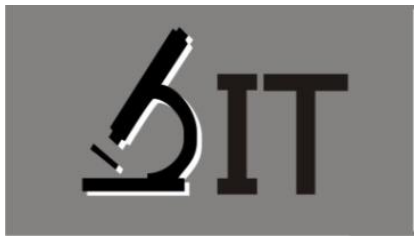

p-ISSN : 2597-8977

e-ISSN : 2597-8985

Firda Widya Sari *)

Universitas Negeri Makassar

Nurhayani H. Muhiddin

Universitas Negeri Makassar

Sitti Rahma Yunus

Universitas Negeri Makassar

Sitti Saenab

Universitas Negeri Makassar

*) Correspondence Author: firdawidyasari17@mail.com

\section{PENGARUH MODEL PEMBELAJARAN KOOPERATIF TIPE MAKE A MATCH TERHADAP HASIL BELAJAR PESERTA DIDIK KELAS VIII SMPN 4 TANASITOLO (STUDI PADA MATERI ZAT ADITIF DAN ADIKTIF)}

Abstrak: Penelitian ini bertujuan untuk mengetahui peningkatan hasil belajar peserta didik yang diajar dan tanpa diajar menggunakan Model Pembelajaran Kooperatif tipe make a match pada peserta didik kelas VIII SMP Negeri 4 Tanasitolo. Penelitian ini merupakan Quasi Experimental (eksperimen semu) dengan menggunakan desain penelitian Nonequivalent Control Group Design. Populasi penelitian adalah seluruh peserta didik kelas VIII SMPN 4 Tanasitolo yang terdiri dari 2 kelas. Pengambilan sampel melalui teknik sampling jenuh dan diperoleh kelas VIII 1 sebagai kelas eksperimen dan VIII 2 sebagai kelas Kontrol. Instrumen tes hasil belajar berupa pilihan ganda berjumlah 25 item soal. Teknik pengumpulan data adalah dengan pemberian Pretest dan Posttest. Analisis data dilakukan dengan analisis statistik deskriptif. Hasil belajar peserta didik kelas eksperimen yang diajarkan menggunakan model kooperatif tipe make a match diperoleh skor rata-rata $\mathrm{N}$-Gain 0,62 pada kategori sedang dan kelas kontrol yang diajarkan tanpa menggunakan model kooperatif tipe make a match yaitu 0,49 pada kategori sedang. Hasil penelitian menunjukkan terdapat pengaruh berdasarkan perbedaan hasil skor rata-rata $\mathrm{N}$-Gain yang diperolah dan hasil belajar peserta didik meningkat dengan menggunakan model pembelajaran kooperatif tipe make a match serta terdapat perbedaan hasil belajar kelas eksperimen dan kelas kontrol.

Kata Kunci: Make a Match, Hasil Belajar.

Abstract: The purpose of this study is to determine the enhancement of students' learning outcomes that taught using Make A Match type of cooperative learning model. This research is a Quasi Experimental using the Nonequivalent Control Group Design. The study population was all students of class VIII SMPN 4 Tanasitolo consisting of 2 classes. Sampling through saturated sampling technique and obtained class VIII 1 as an experiment class and VIII 2 as a control class. The instrument of learning outcomes is 25 questions of multiple choice test. Data collection techniques were giving Pretest and Posttest. Data analysis was performed using descriptive analysis. Students' learning outcomes in experiment class that taught using Make A Match type of cooperative learning model obtained an average score of $\mathrm{N}$-Gain 0.62 in medium category and control class taught without using Make A Match type of cooperative learning model that is 0.49 in medium category. The results showed that there was an effect based on differences in the results of the average $\mathrm{N}$-Gain score obtained and student learning outcomes increased using Make A Match type of cooperative learning model and there were differences in learning outcomes for the experimental class and the control class.

Keyword: Make a Match, Learning Outcomes 


\section{PENDAHULUAN}

Undang-Undang Nomor 20 Tahun 2003 tentang Sistem Pendidikan Nasional, Pasal 1 angka 1 menyatakan bahwa pendidikan adalah usaha sadar dan terencana untuk mewujudkan suasana belajar dan proses pembelajaran agar peserta didik secara aktif mengembangkan potensi dirinya untuk memiliki kekuatan spiritual keagamaan, pengendalian diri, kepribadian, kecerdasan, akhlak mulia, serta keterampilan yang diperlukan dirinya, masyarakat, bangsa dan Negara. Sehingga guru harus menciptakan suasana belajar yang membantu peserta didik dalam belajar agar mencapai tujuan-tujuan pembelajaran yang di ajarkan.

Observasi menunjukkan adanya perbedaan karakteristik belajar dari peserta didik menyebabkan cara belajar dan cara merespon terhadap pelajaran tidaklah sama, sehingga pada saat proses pembelajaran sedang berlangsung diperlukan metode pembelajaran yang dapat membuat peserta didik terfokus pada pelajaran yang diajarkan oleh guru. Guru harus cerdas dalam memilih metode pembelajaran agar hasil belajar peserta didik mencapai yang diharapkan.

Berdasarkan observasi yang telah dilakukan pada tanggal 12 februari 2019 dengan melakukan wawancara dengan guru IPA kelas VIII di SMP Negeri 4 Tanasitolo, pembelajaran IPA yang berlangsung saat ini menggunakan pembelajaran langsung dengan menggunakan metode ceramah kemudian diberikan tugas dan dikerjakan di dalam kelas. Model pembelajaran yang digunakan oleh guru yaitu model pembelajaran langsung dengan metode ceramah namun peserta didik tidak banyak yang terlibat aktif dalam proses pembelajaran, jikapun ada hanya 2 atau 3 orang yang aktif. Saat proses pembelajaran apabila peserta didik diberikan tugas berkelompok, hanya satu yang mengerjakan tugas tersebut dan perolehan hasil belajar cenderung di bawah standar kelulusan yaitu di bawah nilai 75. Adapun hasil belajar dari peserta didik hanya 14 peserta didik yang memperoleh nilai tuntas dari berbagai materi pelajaran yang telah diajarkan oleh guru.

Observasi berikutnya telah dilakukan oleh peneliti pada tanggal 25 februari 2019 data hasil belajar peserta didik yang diperoleh dari guru mata pelajaran IPA dari 37 peserta didik terdapat 6 orang peserta didik yang tuntas dan 31 peserta didik lainnya memperoleh hasil belajar di bawah standar atau harus remedial. Secara keseluruhan hasil belajar peserta didik berada pada kategori rendah.

Model pembelajaran maupun strategi yang dilakukan guru bertujuan untuk membuat para peserta didik aktif dalam proses pembelajaran, memahami pelajaran dan memperoleh hasil belajar yang memuaskan. Namun tidak semua peserta didik terpancing untuk aktif dalam kelas dengan model pembelajaran oleh guru. Belajar IPA adalah belajar mengenai alam dan lingkungan sekitar jadi yang diperlukan bukan hanya menghafalkan tetapi harus dipahami.

Cooperative learning adalah salah satu bentuk pembelajaran yang berdasarkan paham kontruktivisme. Pembelajaran kooperatif merupakan model pembelajaran yang mengutamakan kerja sama di antara peserta didik untuk mencapai tujuan pembelajaran. Jika ditinjau lebih mendalam, terdapat beberapa alasan penting mengapa cooperative learning ini perlu diterapkan di sekolah-sekolah atau madrasah-madrasah untuk meningkatkan prestasi belajar peserta didiknya. Alasan utama adalah karena seiring dengan proses globalisasi, terjadi juga transformasi social, ekonomi, dan demografis yang mengharuskan sekolah-sekolah termasuk juga madrasah-madrasah untuk lebih menyiapkan peserta didik dengan keterampilan-keterampilan (life skill) bermasyarakat. Dengan demikian mereka mampu berpartisipasi aktif dalam dunia yang cepat berubah dan berkembang pesat (Fathurrohman, 2017).

Model pembelajaran Kooperatif tipe Make a Match merupakan model yang menciptakan hubungan baik antara guru dan peserta didik. Guru mengajak peserta didik bersenang-senang dalam permainan. Kesenangan tersebut juga dapat mengenai materi dan peserta didik dapat belajar secara langsung maupun tidak langsung (Supriatin, 2017).

Menurut (Wandy, 2017) bahwa salah satu cara untuk mengaktifkan peserta didik dalam proses belajar adalah dengan penerapan metode Make a Match. Model pembelajaran kooperatif 
tipe Make a Match ini menempatkan peserta didik pada posisi sangat dominan dalam proses pembelajaran dimana semua peserta didik dalam setiap kelompok diharuskan untuk berusaha memahami dan menguasai materi yang sedang diajarkan dan selalu aktif ketika kerja kelompok sehingga saat ditunjuk untuk mempresentasikan jawabannya, mereka dapat menyumbangkan skor bagi kelompoknya. Metode pembelajaran ini dapat menciptakan suasana pembelajaran yang aktif sehingga akan berdampak terhadap peningkatan hasil belajar peserta didik.

Model pembelajaran Cooperative Learning tipe Make a Match berpengaruh postitif terhadap hasil belajar kognitif peserta didik SMP (Apriyani, Maryanto, \& Nurohman, 2016). Dalam penelitian ini terdapat perbedaan antara kelas eksperimen dengan kelas kontrol berupa pengaruh positif. Kelas eksperimen memiliki nilai lebih besar dibandingkan nilai kelas kontrol.

Penelitian serupa juga dilakukan oleh Mikran, Pasaribu, \& Darmadi (2012) yaitu penerapan model pembelajaran kooperatif tipe Make a Match dapat meningkatkan hasil belajar fisika peserta didik kelas VIIA SMP Negeri 1 Tomini pada konsep gerak dan keaktifan peserta didik nampak dalam proses pembelajaran. Hal ini disebabkan karena telah terjadi saling berinteraksi antar peserta didik yang menuntut mereka saling menghargai pendapat, tidak merasa takut baik itu takut salah maupun takut ditertawakan atau dianggap sepeleh oleh peserta didik lainnya. Peserta didik mulai berani mengemukakan pertanyaan, pendapat dan menjawab pertanyaan peserta didik lain dan diperoleh nilai ketuntasan belajar sebesar $94 \%$.

Berdasarkan rumusan masalah yang telah diuraikan, maka tujuan dari penelitian yaitu untuk mengetahui peningkatan hasil belajar peserta didik yang diajar menggunakan Model Pembelajaran Kooperatif tipe Make A Match pada peserta didik kelas VIII SMP Negeri 4 Tanasitolo, dan untuk mengetahui peningkatan hasil belajar peserta didik yang diajar tanpa diajar menggunakan Model Pembelajaran Kooperatif tipe Make A Match pada peserta didik kelas VIII SMP Negeri 4 Tanasitolo serta untuk mengetahui perbedaan hasil belajar peserta didik yang diajar menggunakan Model Pembelajaran Kooperatif tipe Make A Match dan tidak diajar menggunakan Model Pembelajaran Kooperatif tipe Make A Match pada peserta didik kelas VIII SMP Negeri 4 Tanasitolo.

\section{METODE}

Jenis penelitian yang digunakan adalah quasi experimental dengan desain penelitian yaitu Nonequivalent Control Group Design, pada desain ini kelompok eksperimen maupun kelompok kontrol tidak dipilih secara random. Penelitian dilaksanakan pada Semester Ganjil Tahun Ajaran 2019/2020 di SMP Negeri 4 Tanasitolo Kab Wajo.

Pengambilan sampel pada penelitian ini menggunakan teknik sampling jenuh. Sampling jenuh adalah teknik penentuan sampel bila semua anggota populasi digunakan sebagai sampel. Jumlah sampel yang digunakan yaitu sebanyak 38 peserta didik dengan sampel penelitian kelas VIII 1 sebagai kelas eksperimen dengan jumlah peserta didik 19 orang dan kelas VIII 2 sebagai kelas kontrol sebanyak 19 orang peserta didik.

Pengumpulan data hasil belajar pada aspek kognitif diberikan kepada peserta didik dalam bentuk soal pilihan ganda sebanyak 25 nomor dari 10 indikator dengan tingkat kognitif c1 sebanyak 10 nomor, c2 sebanyak nomor 7, c3 sebanyak 2 nomor dan c4 sebanyak 6 nomor. Tes hasil belajar ini diberikan pada saat pretest dan posttest. Data yang diperoleh dalam penelitian ini berbentuk data kuantitatif dan dianalisis menggunakan analisis statistik deskriptif. Statistik deskriptif dapat digunakan bila peneliti hanya ingin mendeskripsikan data sampel dan tidak ingin membuat kesimpulan yang berlaku untuk populasi dimana sampel diambil.

Hasil belajar pada kelas eksperimen maupun kelas kontrol disajikan dalam bentuk pengkategorian $\mathrm{N}$-gain yang diperoleh dari data pretest dan posttest. Peningkatan skor hasil belajar peserta didik antara pretest dan posttest dihitung dengan rumus normalisasi Gain atau g faktor (Gain Score) (Hake, 1999). 


\section{HASIL DAN PEMBAHASAN}

1. Hasil

\section{a. Analisis Deskriptif}

Data skor pretest dan posttest pada kelas Cooperative tipe Make a Match dan kelas kontrol berdasarkan analisis statistik deskriptif dapat dilihat pada Tabel 1.

Tabel 1. Hasil Analisis Statistik Deskriptif Skor Pretest dan Posttest Hasil Belajar Kelas Cooperative tipe Make a Match dan Kelas Kontrol

\begin{tabular}{clcccc}
\hline \multirow{2}{*}{ No. } & Statistik & \multicolumn{2}{c}{$\begin{array}{c}\text { Kelas Cooperative tipe Make } a \\
\text { Match }\end{array}$} & \multicolumn{2}{c}{ Kelas Kontrol } \\
\cline { 3 - 6 } & & Pretest & Posttest & Pretest & Posttest \\
\hline & & 19 & 19 & 19 & 19 \\
\hline 1. & Jumlah sampel & 25 & 25 & 25 & 25 \\
2 & Skor Total Tertinggi & 0 & 0 & 0 & 0 \\
3 & Skor Total Terendah & 21 & 25 & 18 & 22 \\
4 & Skor tertinggi & 6 & 16 & 4 & 15 \\
5 & Skor terendah & 13,84 & 21 & 12,47 & 18,79 \\
6 & Skor rata-rata & 3,96 & 2,18 & 3,89 & 2,23 \\
7 & Standar deviasi & 15,69 & 4,77 & 15,20 & 4,95 \\
8 & Varians & & & & \\
\hline
\end{tabular}

Pada Tabel 1 hasil analisis deskriptif, data hasil belajar peserta didik dapat dideskripsikan yaitu hasil belajar IPA pada kelas Cooperative tipe Make a Match yang merupakan kelas yang diberikan perlakuan model pembelajaran kooperatif tipe make a match dan kelas kontrol yang diajar tanpa menggunakan model pembelajaran kooperatif tipe make a match.

Hasil pretest kelas Cooperative tipe Make a Match diperoleh skor rata-rata peserta didik 13,84 dan untuk kelas kontrol diperoleh skor rata-rata 12,47, dengan skor tertinggi yang diperoleh 21 untuk kelas eksperimen dan skor tertinggi 18 pada kelas kontrol, skor terendah pada Cooperative tipe Make a Match adalah 6 dan skor terendah pada kelas kontrol yaitu 4. Standar deviasi pada kelas Cooperative tipe Make a Match 3,96 dan 3,89 untuk standar deviasi kelas kontrol, pada kelas Cooperative tipe Make a Match varians datanya adalah 15,69 dan 15,20 untuk varians kelas kontrol.

Hasil posttest pada kelas Cooperative tipe Make a Match, diperoleh skor rata-rata peserta didik 21 dan skor rata-rata peserta didik pada kelas kontrol 18,79. Skor tertinggi yang diperoleh pada kelas Cooperative tipe Make a Match yaitu 25 dan skor tertinggi yang dicapai pada kelas kontrol yaitu 22, skor terendah yang dicapai pada kelas Cooperative tipe Make a Match adalah 16 dan untuk kelas kontrol skor terendah yang didapatkan adalah 15. Standar deviasi pada kelas Cooperative tipe Make a Match yaitu 2,18 dan standar deviasi pada kelas kontrol adalah 2,23. Varians pada kelas Cooperative tipe Make a Match yaitu 4.77 dan 4.95 untuk varians pada kelas kontrol.

Setelah dilakukan analisis terhadap data skor pretest dan posttest yang telah di peroleh pada kelas Cooperative tipe Make a Match dan kelas kontrol dapat diketahui peningkatan tiap indikator hasil belajar pada Tabel 2 . 
Tabel 2. Perbedaan Skor N-Gain Setiap Indikator Hasil Belajar Kelas Cooperative tipe Make a Match dan Kelas Kontrol

\begin{tabular}{|c|c|c|c|c|}
\hline \multirow[b]{2}{*}{ No } & \multirow[b]{2}{*}{ Indikator } & \multirow[b]{2}{*}{$\begin{array}{l}\text { Jumlah } \\
\text { soal }\end{array}$} & \multicolumn{2}{|c|}{ Pencapaian N-Gain } \\
\hline & & & $\begin{array}{c}\text { Cooperative } \\
\text { tipe Make a } \\
\text { Match }\end{array}$ & Kontrol \\
\hline 1 & Menyebutkan jenis - jenis zat aditif & 3 & 1 & 0,71 \\
\hline 2 & Memberi contoh zat aditif alami dan buatan & 2 & 0,74 & 0,64 \\
\hline 3 & $\begin{array}{l}\text { Mengidentifikasi berbagai zat aditif dalam makanan dan } \\
\text { minuman }\end{array}$ & 3 & 0,61 & 0,33 \\
\hline 4 & $\begin{array}{l}\text { Menyelediki pewarna alami dan buatan pada makanan dan } \\
\text { minuman }\end{array}$ & 2 & 0,18 & 0,36 \\
\hline 5 & $\begin{array}{l}\text { Menganalisis perbedaan pemanis alami dan buatan pada } \\
\text { makanan dan minuman }\end{array}$ & 2 & 0,38 & 0,56 \\
\hline 6 & Menemukan solusi pengganti zat aditif buatan & 3 & 0,52 & 0,40 \\
\hline 7 & Menyebutkan jenis-jenis zat adiktif & 5 & 0,84 & 0,47 \\
\hline 8 & Menjelaskan dampak penggunaan zat adiktif bagi kesehatan & 2 & 0,67 & 0,53 \\
\hline 9 & Membuat model tentang bahaya rokok bagi kesehatan & 2 & 0,17 & 0,56 \\
\hline 10 & $\begin{array}{l}\text { Menjelaskan beberapa upaya untuk menjaga diri dari bahaya } \\
\text { narkoba di masyarakat }\end{array}$ & 1 & 0,86 & 0,43 \\
\hline
\end{tabular}

Skor pretest dan skor posttest dari kedua kelas sampel penelitian yaitu kelas eksperimen dan kelas kontrol, dilakukan uji $\mathrm{N}$-Gain untuk mengetahui peningkatan hasil belajar peserta didik seperti pada Tabel 3 .

Tabel 3. Rata-rata Skor N-gain Hasil Belajar Peserta Didik Kelas Cooperative tipe Make a Match dan Kelas Kontrol

\begin{tabular}{ccccc}
\hline \multirow{2}{*}{ Kelas } & \multicolumn{2}{c}{ Skor } & \multirow{2}{*}{ Rata-Rata Skor N-Gain } & Kategori \\
\cline { 2 - 3 } & Pretest & Posttest & & Sedang \\
\hline $\begin{array}{c}\text { Kelas Cooperative tipe Make a } \\
\text { Match }\end{array}$ & 13,842 & 21 & 0,616 & Sedang \\
Kelas Kontrol & 12,474 & 18,789 & 0,495 & S \\
\hline
\end{tabular}

Setelah menilai LKPD yang dikerjakan peserta didik berdasarkan rubrik yang telah dibuat maka diperoleh hasil sebagai berikut.

Tabel 4. Hasil Penilaian Lembar Kerja Peserta Didik Kelas Cooperative tipe Make a Match

\begin{tabular}{cccc}
\hline \multirow{2}{*}{ Kelompok } & \multicolumn{3}{c}{ Pertemuan Ke- } \\
\cline { 2 - 4 } & $\mathrm{I}$ & $\mathrm{II}$ & III \\
\hline 1 & 57,62 & 85 & 70 \\
2 & 69,49 & 95 & 90 \\
3 & 72,88 & 90 & 80 \\
4 & 72,88 & 85 & 70 \\
\hline Rata-rata & 68,22 & 88,75 & 77,5 \\
\hline
\end{tabular}


Tabel 5. Hasil Penilaian Lembar Kerja Peserta Didik Kelas Kontrol

\begin{tabular}{cccc}
\hline Kelompok & \multicolumn{3}{c}{ Pertemuan Ke- } \\
\cline { 2 - 4 } & I & II & III \\
2 & 52,54 & 90 & 60 \\
3 & 66,10 & 90 & 60 \\
4 & 54,23 & 85 & 90 \\
Rata-rata & 76,27 & 75 & 60 \\
\hline
\end{tabular}

\section{Pembahasan}

Penelitian yang telah dilakukan dengan mengukur hasil belajar peserta didik yang menggunakan model pembelajaran kooperatif tipe make a match pada kelas Cooperative tipe Make a Match lebih tinggi dibandingkan kelas kontrol seperti yang terlihat pada Tabel $1 \mathrm{Hal}$ ini disebabkan karena model pembelajaran kooperatif tipe make a match memberikan kesempatan peserta didik melalui kartu soal dan kartu jawaban yang digunakan saat proses pembelajaran untuk lebih mendalami pelajaran yang dipelajari. Menurut Wardani, Fuady, \& Andayani (2016) model pembelajaran make a match adalah model pembelajaran yang didesain seperti permainan kartu yang berisi soal dan jawaban materi yang sedang dipelajari. Model pembelajaran ini siswa harus berkonsentrasi dan berpartisipasi dalam melaksanakan setiap langkah-langkah pembelajarannya. Selain itu pembelajaran ini merupakan model pembelajaran yang menarik sehingga membuat belajar menjadi lebih menyenangkan. Semakin seringnya peserta didik menyelesaikan soal dalam model ini akan membuat mereka lebih memahami materi karena terbiasa memecahkan soal-soal serupa. Hasil belajar peserta didik yang diukur pada penelitian ini hanya pada aspek kognitif. Adanya perbedaan hasil belajar kelas Cooperative tipe Make a Match dan kelas kontrol dipengaruhi juga oleh keaktifan peserta didik. Peserta didik tergolong aktif itu ketika memperhatikan guru, bekerjasama aktif mengemukakan pendapat jadi materi yang diterima oleh peserta didik dapat dipahami dan diingat dengan baik kemudian saat diberikan tes, peserta didik dapat menjawab soal dengan mengingat dari apa yang mereka pelajari. Menurut (Paramita, Utami, \& Isnaeni, 2012), Ketuntasan hasil belajar kelas eksperimen meningkat dikarenakan pembelajaran dengan menggunakan permainan menciptakan suasana menyenangkan bagi siswa. Pembelajaran dengan menggunakan model cooperative learning tipe make a match dapat meningkatkan hasil belajar siswa.

Hasil belajar peserta didik yang diukur menggunakan $\mathrm{N}$-Gain pada analisis statistik deskriptif dilihat di Tabel 3 pada kelas Cooperative tipe Make a Match diperoleh skor rata-rata 0.616 berada pada kategori sedang sedangkan dengan skor rata-rata 0.495 berada pada kategori sedang untuk kelas kontrol. Walaupun skor rata-rata N-Gain hasil belajar pada kelas Cooperative tipe Make a Match dan kelas kontrol berada pada kategori sedang namun terdapat perbedaan skor hal ini membuktikan model pembelajaran kooperatif tipe make a match dapat meningkatkan hasil belajar. Dengan menggunakan model pembelajaran kooperatif tipe make a match dilihat dari pelaksanaannya model pembelajaran make a match membuat pesera didik bekerja dalam tim dan semua siswa harus menguasai pelajaran tersebut, sehingga peserta didik dituntut aktif. Apabila peserta didik menguasai pelajaran, maka hasil belajar juga akan meningkat. Kelas Cooperative tipe Make a Match yang diajar menggunakan model pembelajaran kooperatif tipe make a match lebih tinggi dibandingkan kelas kontrol yang tidak diajar menggunakan model pembelajaran kooperatif tipe make a match. Dalam Fitriati \& Hadi (2014) pembelajaran kooperatif tipe make a match lebih efektif dalam meningkatkan hasil belajar siswa. Hal ini disebabkan karena kerjasama antar siswa terjalin dengan lancar, guru maupun siswa sudah bisa menjalankan fungsi dan perannya dalam metode pembelajaran make a match dengan baik serta dapat meningkatkan keaktifan belajar siswa. Hal ini dikarenakan siswa mendapatkan pengalaman, disamping menumbuhkan tanggung jawab, 
kerjasama, keterlibatan dan semangat belajar dan persaingan sehat, sehingga pembelajaran dapat berjalan dengan efektif.

Hasil analisis tiap indikator hasil belajar pada Tabel 2 kelas Cooperative tipe Make a Match lebih tinggi dari kelas kontrol. Rata-rata skor N-Gain tiap indikator hasil belajar kelas Cooperative tipe Make a Match berada pada kategori tinggi, dilihat dari 10 indikator hasil belajar peserta didik, pada indikator 1,2,7 dan 10 berada pada kategori tinggi, indikator 3,5,6 dan 8 berada pada kategori sedang dan indikator 4 dan 9 berada pada kategori rendah hal ini dipengaruhi oleh model pembelajaran yang digunakan yaitu model pembelajaran kooperatif tipe Make a Match dimana pada proses pembelajaran saat menggunakan model ini peserta didik dituntut untuk memahami dan mengingat dengan dengan baik setiap materi yang diajarkan saat dibagikan kartu jawaban ataupun kartu soal kepada peserta didik. Pencapaian skor hasil belajar tiap indikator berada pada kategori sedang dari 10 indikator, indikator 1 berada pada kategori tinggi dan 9 indikator lainnya berada pada kategori sedang hal ini disebabkan pada kelas kontrol model pembelajaran yang diterapkan tidak menggunakan model pembelajaran kooperatif tipe Make a Match di mana pada saat proses pembelajaran pendidik yang menjelaskan dari awal hingga akhir pelajaran atau dengan kata lain pendidik lebih dominan ceramah jadi kemungkinan peserta didik agak bosan. Seperti yang diketahui hasil belajar peserta didik berpengaruh pada proses pembelajaran dalam kelas. Apabila pada proses pembelajaran berkesan maka akan meninggalkan kesan dalam ingatan peserta didik mengenai materi pelajaran yang telah dipelajari, dan akan membuat hasil belajar peserta didik lebih tinggi. Proses pembelajaran pada kelas Cooperative tipe Make a Match dan kelas kontrol menggunakan Lembar Kerja Peserta Didik (LKPD) yang sama. Terdapat perbedaan skor hasil jawaban Lembar Kerja Peserta Didik (LKPD) antara kelas kontrol dan kelas Cooperative tipe Make a Match dengan jawaban LKPD kelas Cooperative tipe Make a Match lebih tinggi dibandingkan kelas kontrol.

\section{KESIMPULAN}

Berdasarkan hasil penelitian yang telah dilakukan tentang pengaruh model pembelajaran kooperatif tipe make a match terhadap hasil belajar peserta didik kelas VIII SMPN 4 Tanasitolo dapat disimpulkan sebagai berikut:

1. Peningkatan hasil belajar peserta didik kelas VIII SMPN 4 Tanasitolo yang diajar menggunakan model pembelajaran kooperatif tipe make a match pada materi zat aditif dan zat adiktif berkategori sedang dengan skor rata-rata N-gain 0,616.

2. Peningkatan hasil belajar peserta didik kelas VIII SMPN 4 Tanasitolo yang diajar tanpa menggunakan model pembelajaran kooperatif tipe make a match berada pada kategori sedang engan skor rata-rata N-gain 0,495.

3. Terdapat perbedaan hasil belajar peserta didik kelas VIII SMPN 4 Tanasitolo yang diajar menggunakan model pembelajaran kooperatif tipe make a match pada materi zat aditif dan zat adiktif dan yang tidak diajar menggunakan model pembelajaran kooperatif tipe make a match.

\section{DAFTAR PUSTAKA}

Apriyani, Maryanto, A., \& Nurohman, S. (2016). Effects Of Cooperative Learning Model Make A Match Type Of Learning Against Sciencesocial Skills And Outcomes Cognitive Student Junior High School. Jurnal Pendidikan Ilmu Pengetahuan Alam, V, 6.

Fathurrohman, M. (2017). Model-model pembelajaran inovatif. Jogjakarta: Ar-Ruzz Media. 
Fitriati, E., \& Hadi, S. (2014). Keefektifan Metode Pembelajaran Make A Match Terhadap Hasil Belajar Kompetensi Dasar Permintaan dan Penawaran Uang pada Siswa Kelas X Sma Negeri 16 Semarang . Economic Education Analysis Journal , 70.

Hake, R. R. (1999). Analyzing Change/Gain Scores. Dept. of Physics, Indiana University , 2.

Kunandar, D. (2014). Penilaian Autentik(Penilaian hasil belajar peserta didik berdasarkan kurikulum 2013. Jakarta: rajawali pers.

Mikran, Pasaribu, M., \& Darmadi, I. W. (2012). Penerapan Model Pembelajaran Kooperatif Make A Match untuk Meningkatkan Hasil Belajar Siswa Kelas VIIA SMP Negeri 1 Tomini Pada Konsep Gerak. jurnal Pendidikan Fisika Tadulako, II, 16.

Paramita, I., Utami, N. R., \& Isnaeni, W. (2012). Penggunaan Model Cooperative Learning Type Make-A-Match Terhadap Hasil Belajar Sistem Gerak. Journal of Biology Education , 287.

Supriatin, A. I. (2017). Penggunaan Kartu Make A Match untuk Meningkatkan Kemampuan Siswa dalam Membedakan Jenis-Jenis Adaptasi. Jurnal Wahana Pendidikan, IV, 2-4.

Wandy. (2017). Metode Pembelajaran Make A Match Untuk Meningkatkan Hasil Belajar Bahasa Indonesia Siswa Sekolah Menengah Pertama. Jurnal Ilmu Pendidikan Sosial, sains, dan Humaniora, III, 115-116.

Wardani, S. R., Fuady, A., \& Andayani. (2016). Peningkatan Keaktifan dan Kemampuan Menulis Teks Anekdot dengan Menggunakan Model Pembelajaran Make A Match pada Siswa Kelas X SMK. Jurnal Penelitian Bahasa, Sastra Indonesia dan Pengajarannya.

Yulianti. (2016). Pengembangan Alat Evaluasi Hasil Belajar Mata Pelajaran Pendidikan Agama Islam Berbasis Taksonomi Bloom Dua Dimensi. Journal of Islamic Education Studies, I, 415-416.

\section{Firda Widya Sari}

Mahasiswa Program Studi Pendidikan IPA FMIPA UNM, aktif melakukan penelitian pada bidang Pendidikan IPA, dapat dihubungi melalui email: firdawidyasari17@mail.com

\section{Nurhayani H. Muhiddin}

Dosen Program Studi Pendidikan IPA FMIPA UNM, aktif melakukan penelitian pada bidang Pendidikan IPA, dapat dihubungi melalui email: nurhayanio8@gmail.com

\section{Sitti Rahma Yunus}

Dosen Program Studi Pendidikan IPA FMIPA UNM, aktif melakukan penelitian pada bidang Pendidikan IPA, dapat dihubungi melalui email: sitti.rahma.yunus@unm.ac.id

\section{Sitti Saenab}

Dosen Program Studi Pendidikan IPA FMIPA UNM, aktif melakukan penelitian pada bidang Pendidikan IPA, dapat dihubungi melalui email: sitti.saenab@unm.ac.id 